\title{
KAIDAH DALAM INTERAKSI DAN INTERPRETASI TERHADAP NAS-NAS TANDA HARI KIAMAT
}

\section{Rules of Interaction and Interpretation toward the Passages of the Doomsday}

\section{Lukmanul Hakim Sudahnan}

King Saud University, Arab Saudi

Email : luqmanulhakim81@gmail.com

Muhammad Yusram

Sekolah Tinggi Ilmu Islam dan Bahasa Arab (STIBA) Makassar Email : yusrananshar@stiba.ac.id

Keywords :
interpretation, doomsday, passages, rules,
badith
badith

\begin{abstract}
This study aimed to examine the types of interpretations of passages about the signs of doomsday, the wisdom of passages on tribulations and signs of doomsday, the law referring concordance between signs of doomsday and specific occurrences or individuals, and rules in interpreting passages about the signs of doomsday. This research employed qualitative-descriptive approach with content analysis technique and library research. The results of the study show that: (1) there are two types of interpretations of the passages on the signs of doomsday, those are: first, describing those passages and describing the characteristics and details of events according to what is mentioned in the passages; second, identifying the concordance between signs of doomsday and specific occurrences or individuals; (2) among the wisdoms of the passages related to end of time: as proof of the truth of the Prophet's message, as a test for the faith of men, and so that he prepares himself heading toward the end of the day; (3) the law referring the concordance between signs of doomsday and specific occurrences or individuals is allowed, by ensuring the validity (authenticity) of the narrations and not determining the truth of the concordance; (4) rules or principles that must be considered in interpreting passages relating to doomsday are to ascertain Quran and Sunnah as the primary source, veriffing the validity of the hadith, not inventing (takalluf), being thorough, not precisely determining the year or the time of doomsday. ABSTRAK
\end{abstract}

Kata kunci :

interpretasi, kiamat, nas, rambu, hadis

\begin{abstract}
Penelitian ini bertujuan untuk mengkaji jenis interpretasi nas-nas tentang tandatanda kiamat, hikmah dari nas-nas tersebut, hukum mendudukkan kesesuaian tanda-tanda kiamat dengan suatu peristiwa atau individu, dan rambu-rambu interpretasi nas-nas tentang tanda-tanda kiamat. Penelitian ini menggunakan metode pendekatan kualitatif-deskriptif dengan teknik content analysis (analisis isi) dan riset kepustakaan (library research). Hasil penelitian menunjukkan bahwa : (1) jenis interpretasi nas-nas tentang tanda-tanda kiamat ini ada dua, yaitu : pertama, mendeskripsikan nas-nas tersebut dan memaparkan sifat dan rincian peristiwanya sesuai yang dikandung oleh nas tersebut; kedua, mendudukkan kesesuaian nas-nas terkait tanda-tanda kiamat pada peristiwa atau tokoh atau hal tertentu; (2) diantara hikmah nas-nas terkait akhir zaman adalah sebagai bukti kebenaran risalah Nabi, sebagai salah satu ujian bagi keimanan hamba, dan agar seorang hamba mempersiapkan diri dalam menghadapi hari akhir; (3) hukum mendudukkan kesesuaian tanda-tanda kiamat dengan suatu peristiwa atau individu adalah boleh, dengan syarat kehati-hatian dalam memastikan kevalidan (kesahihan) riwayatriwayatnya dan tidak memastikan kebenaran penentuan tersebut; (4) rambu-rambu atau kaidah yang wajib diperhatikan dalam interpretasi nas-nas terkait hari kiamat adalah menjadikan Alquran dan sunah sebagai sumber utama, melakukan verifikasi kevalidan hadisnya, tidak dipaksakan (takalluf), bersikap hati-hati, tidak menetapkan penentuan waktu terjadinya tanda kiamat, dan tidak memastikan kebenaran interpretasi tersebut.
\end{abstract}

Riwayat artikel : Diterima : 9 Desember 2019; Direvisi : 10 Desember 2019; Disetujui : 17 Desember 2019; Tersedia online: Desember 2019.

How to cite : Sudahnan, L.H., Yusram, M. (2019). Kaidah Dalam Interaksi dan Interpretasi Terhadap Nas-Nas Tanda Hari Kiamat. NUKHBATUL 'ULUM : Jurnal Bidang Kajian Islam, 5(2), 64-87. https://doi.org/10.36701/nukhbah.v5i2.85 


\section{PENDAHULUAN}

Meneropong suatu peristiwa besar adalah salah satu perkara yang menarik minat setiap insan. Ketertarikan itu akan semakin membuncah manakala hakikat peristiwa tersebut mesti berpijak pada dalil-dalil syar'i dan berkaitan secara langsung dengan keyakinan terhadap nas-nas yang datang dari Alquran dan Hadis.

Di antara perkara tersebut adalah informasi seputar tanda-tanda kiamat dan peristiwa-peristiwa besar yang mengiringinya. Ia tak hanya menggelitik minat para peneliti muslim dalam membedahnya, tetapi lebih dari itu, sebagian mereka bahkan sudah sampai pada level menyesuaikan atau mencocokkannya dengan berbagai peristiwa yang terjadi atau pada sosok individu tertentu. ${ }^{1}$

Kajian tersebut ${ }^{2}$ semakin banyak di tengah masyarakat disebabkan tersebarnya referensi yang dapat diperoleh secara mudah dari berbagai media, seperti Isrä ìliyyät (kabar-kabar dari Ahli Kitab) yang tersebar di kitabkitab kaum muslimin dan riwayatriwayat yang sangat lemah dan palsu yang. Alhasil, berbagai buku atau literatur kontemporer yang meneropong umur dunia, kajian-kajian yang berbasis pada dugaan, taksiran atau ramalan terkait waktu munculnya Imam Mahdi, keluarnya Dajjal, turunnya Nabi Isa dan tanda-tanda kiamat lainnya (Al-'Ujairi, $1433 \mathrm{H}$ ).

${ }^{1}$ Beberapa tema buku kontemporer yang disebutkan dalam artikel ini dapat menjadi bukti ketertarikan tersebut.

${ }^{2}$ Maksudnya adalah kajian yang mencocokkan tanda kiamat dengan peristiwa atau individu tertentu.
Cukup banyak buku-buku kontemporer yang ditulis untuk 'meramal' kejadian akhir dunia ini, dan sebagian buku tersebut cukup menyedot minat masyarakat untuk membacanya ${ }^{3}$. Di antaranya, 'Umr Ummatil-Isläm, Qurb Zuhüril-Mabdiy 'Alaibis-Salam karya Amin Muhammad Jamaluddin, Harmajidūn (Armagedon); Äkbirul-Bayān Yà Ummatal-Isläm karya Amin Muhammad Jamaluddin, AlQiyāmah Aș-Sugrā 'Alal-Abwāb karya Faruq Ad-Dasūqiy, Radd As-Sihàm 'An Kitäb 'Umr Ummatil-Isläm karya Amin Muhammad Jamaluddin, dan AlMufäja ah, Busyräka Yà Quds karya Muhammad Isa Daud.

Di samping itu, ada sebagian dai atau ustaz yang memiliki spesialis ilmu seputar akhir zaman. Kajian mereka selalu membahas dan menganalisa seputar tanda-tanda kiamat tersebut, yang diiringi dengan pencocokkan atau penyesuaian dengan realitas atau peristiwa yang ada atau tokoh-tokoh tertentu. Tidak menutup kemungkinan sebagian mereka telah terpengaruh atau terinspirasi oleh bahasan yang terdapat dalam buku-buku yang disebutkan di atas ataupun yang sejenisnya.

Berangkat dari fenomena tersebut, dirasa perlu untuk memberikan penjelasan dan keterangan yang komprehensif kepada umat dan masyarakat, bagaimana syariat Islam mengatur sikap dan interpretasi terhadap nas-nas yang berkaitan dengan hari kiamat dan kejadiankejadian yang mengiringinya. Permasalahan penelitian yang

3 Hal ini terbukti dengan tersebarnya pembahasan tema ini, sebagaimana dicontohkan pada bagian pembahasan rambu-rambu. 
mengemuka untuk dijawab pada penelitian ini adalah bagaimana jenis interpretasi nas-nas tentang tandatanda kiamat? Bagaimana hikmah dari nas-nas tentang fitnah dan tanda-tanda kiamat? Bagaimana hukum mendudukkan kesesuaian tanda-tanda kiamat dengan suatu peristiwa atau individu? Bagaimana rambu-rambu interpretasi nas-nas tentang tandatanda kiamat?

Untuk menjawab permasalahan tersebut, penelitian ini dilakukan dengan tujuan untuk mengkaji jenis interpretasi nas-nas tentang tandatanda kiamat, hikmah dari nas-nas tentang fitnah dan tanda-tanda kiamat, hukum mendudukkan kesesuaian tanda-tanda kiamat dengan suatu peristiwa atau individu, dan ramburambu interpretasi nas-nas tentang tanda-tanda kiamat.

Penelitian ini menggunakan metode pendekatan kualitatif-deskriptif dengan teknik content analysis (analisis isi) dan riset kepustakaan (library research). Teknik content analysis merupakan metode penelitian yang digunakan untuk mengetahui simpulan dari sebuah teks. Atau dengan kata lain, analisis isi merupakan metode penelitian yang ingin mengungkap gagasan penulis yang termanifestasi maupun yang laten. Sementara riset kepustakaan (library research) pada penelitian ini mengunakan jenis dan sumber data sekunder yang diperoleh dari hasil penelitian, artikel dan bukubuku referensi yang membahas topik yang berkaitan dengan tema penelitian (Iskandar dan Aqbar, 2019).

Terdapat beberapa penelitian terdahulu yang juga membahas penafsiran nas-nas terkait hari kiamat dan kejadian-kejadian yang menyertainya, yaitu :

Che' Had (2018), meneliti penafsiran dan pemahaman Umar Sulaiman alAsyqar menyangkut ayat Alquran yang berbicara tentang hari kiamat. Masalah pokok yang dikemukakan oleh penulis adalah tentang penafsiran dan pemahaman Umar Sulaiman al-Asyqar dalam kitabnya al-Ma'ānì al-Hasān fì Tafsir al-Qur'än dan kitab al-'Aqidah fi Düi al-Kitāb wa al-Sunnah : al-Qiyamah al-Kubra mengenai ayat kiamat yang memiliki kemungkinan yang berbeda dengan mufasir lainnya karena berdasarkan metode dan karakteristik penafsiran yang dipakai Umar ketika menafsirkan ayat.

Ahmad dkk. (2018), melakukan kajian untuk memberikan gambaran tentang hari kiamat yang gaib melalui perumpamaan yang nyata di alam dunia. Kajian ini menganalisa beberapa keindahan gaya bahasa Alquran dalam membicarakan persoalan hari kiamat, gambaran tentang kedahsyatannya serta huruhara suasana hari tersebut melalui perumpamaan retorika. Penelitian ini menemukan bahwa berbagai jenis gaya bahasa dan perumpamaan telah digunakan oleh Alquran untuk menggambarkan kedahsyatan hari kiamat seperti kehancuran alam semesta dengan penggunaan tasybih mursal mujmal, tasybih baligh dan sebagainya.

Fauziah (2013), melakukan penelitian untuk mengetahui bagaimana proses terjadinya kiamat dalam tafsir $\mathrm{Al}$ jawabir fi tafsir al-quran al-karim karya Thantawi Jauhari. Penelitian ini menunjukkan bahwa ayat-ayat yang berbicara mengenai kejadian kiamat 
terdapat 47 ayat. Dalam penelitian ini disebutkan bahwa Thantawi Jauhari tidak menolak adanya kiamat, akan tetapi dia menangkap bahwa ayat-ayat tentang kiamat ada isyarat-isyarat untuk ditafsirkan pada masa sekarang, sehingga ayat-ayat yang berbicara mengenai hari kiamat diklasifikasikan ke dalam dua bagian, yakni ayat-ayat kiamat yang mengisyaratkan peristiwa sekarang dan ayat-ayat kiamat dalam konteks yang akan datang. Banyak ayat-ayat tentang kiamat yang diyakini oleh Thantawi sebagai dalil tentang adanya kiamat, dimana tidak semua ayat tersebut dapat ditafsirkan dengan konteks kekinian.

Khozin (1996), melakukan penelitian untuk mengetahui ayat-ayat yang mutasyabihat terkait tanda-tanda akan tibanya hari kiamat, dan penafsiran para mufassir tentang hal tersebut. Penelitian ini menyimpulkan bahwa ayat-ayat mutasyabihat adalah suatu ayat yang tidak jelas pengertian dan maksudnya, tidak ada petunjuk yang kuat yang dapat menunjukkan kepada maknanya yang asli sehingga mengandung beberapa arti yang mengundang penafsiran (ta'wil) dengan mengembalikannya kepada ayat-ayat mubkam.

Adapun penelitian ini, berbeda dengan penelitian-peneltian sebelumnya karena penelitian ini berisi telaah komprehensif dalam beberapa aspek terkait hari kiamat yang tidak didapatkan pada penelitian-penelitian sebelumnya, dimana penelitian ini tidak hanya membahas bagaimana penafsiran ayat atau nas-nas tentang hari kiamat, tetapi juga membahas aspek yang lebih luas yaitu hikmah dari adanya nas-nas tentang fitnah dan tanda-tanda kiamat dan kaidah atau rambu-rambu dalam interpretasi nasnas tentang tanda-tanda kiamat.

\section{PEMBAHASAN}

\section{Jenis Interpretasi Nas-nas Tentang Tanda-tanda Kiamat}

Maksud dari interpretasi nas-nas tentang tanda-tanda kiamat ini ada dua, yaitu : pertama, mendeskripsikan nas-nas tersebut dan memaparkan sifat dan rincian peristiwanya sesuai yang dikandung oleh nas tersebut dan selaras dengan penjelasan para ulama; kedua, upaya untuk mendudukkan kesesuaian nas-nas terkait tanda-tanda kiamat pada peristiwa atau tokoh tertentu, atau memprediksikan terjadinya tanda-tanda kiamat pada waktu, bulan atau tahun tertentu (Al'Ujairi, $1433 \mathrm{H})^{4}$.

Jenis interpretasi pertama merupakan perkara yang lumrah karena upaya tersebut banyak dilakukan oleh para ulama salaf terdahulu, dan secara praktis banyak ditemukan di bukubuku tafsir seperti Tafsi>r At\}T\{abariy, karya At-Thabary bukubuku Syarah Hadis seperti $A l$ Minha>j fi Syarh Sjahi>h Muslim ibn Al-Hajja>j karya An-Nawawiy, Fathul-Bārī karya Ibn Hajar AlAsqalāniy ataupun buku-buku khusus yang membahas tentang fitnah dan tanda-tanda kiamat seperti $A n$ Nihayah fil-Fitan wal-Mala>him, karya Ibn Katsir.

Salah satu contoh praktisnya adalah pemaparan para ulama tentang Da>bbah (binatang raksasa) yang muncul di akhir zaman, sebagaimana

\footnotetext{
4 Dengan sedikit perubahan redaksi kalimat dari
} penulis. 
sabda Rasulullah s\}alla>llahu 'alaihi wa sallam dalam hadis Hużaifah bin Asid radjiyalla>hu 'anhuma>, beliau bersabda,

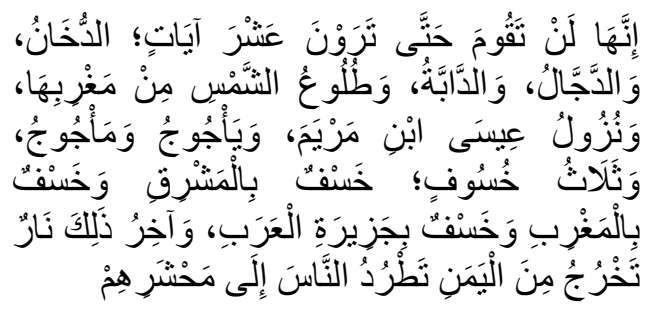

(artinya), "Sungguh ia (kiamat) tidak akan terjadi hingga kalian melihat sepuluh tanda; munculnya kabut, Dajal, Däbbah (binatang raksasa), terbitnya matahari dari barat, turunnya Isa bin Maryam, munculnya Yakjuj dan Makjuj, adanya tiga longsor; longsor di timur, di barat dan di Jazirah Arab, dan yang terakbir adalab munculnya api dari Yaman yang menggiring manusia menuju tempat perkumpulan mereka" 5.

Allah 'Azza wa Jalla juga berfirman,

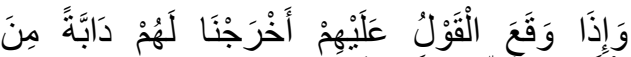

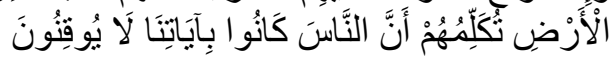

(artinya), "Dan apabila perkataan telah berlaku atas mereka, Kami keluarkan binatang (Däbbab) dari bumi, yang akan mengatakan kepada mereka babwa manusia tidak yakin kepada ayat-ayat Kami'”.

Hadis dan ayat di atas menjelaskan bahwa salah satu tanda kiamat besar adalah munculnya Däbbah. ${ }^{7}$ Tentunya banyak kaum muslimin yang merasa penasaran terhadap makna yang dikandung nas di atas; berupa tempat dan waktu munculnya Dābbah tersebut, jenis binatangnya, serta berbagai hal yang berkaitan

${ }^{5}$.HR Muslim : 7285.

${ }^{6}$ QS. An-Naml: 82.

${ }^{7}$ Lihat: Asyrathus Sa'ah, karya Yusuf Wabil, Hal. 403. dengannya. ${ }^{8}$ Penjelasan hal tersebut tentunya dapat ditemukan dalam banyak referensi; misalnya buku-buku Syarah Hadis, seperti TuhffatulAh\}waz\}̄ karya Al-Mubārakfūriy; atau buku-buku tafsir, seperti Tafsir AțTabariy; atau buku-buku khusus terkait fitnah akhir zaman dan tanda-tanda kiamat, seperti At-Taz\}kirah fi> Ah\}wa>lil-Mauta> wa Umu>rila>khirah karya Al-Qurtubiy dan lain sebagainya. Interpretasi-interpretasi jenis ini sangat populer dan banyak dipaparkan oleh para ulama baik ulama salaf maupun ulama mutakhir.

Adapun interpretasi jenis kedua, maka dapat ditemukan pula praktiknya di kalangan ulama salaf, namun skalanya lebih sedikit dan sangat sempit. Rasulullah s\}allalla>hu 'alaihi wa sallam sendiri ketika memberi peringatan kepada para sahabatsahabatnya terkait tanda-tanda kiamat, beliau menyebutkannya dengan sangat serius, sampai sebagian sahabat menduga bahwa kiamat akan terjadi pada zaman mereka. Oleh karena itu, sebagian dari mereka memperkirakan dan menetapkan kesesuaian hadis terkait Dajal kepada Ibnu Șayyād, bahkan Umar bin Khattab bersumpah di hadapan Nabi sfallalla>hu 'alaihi wa sallam bahwa Ibnu Șayyād adalah Dajal (Al-Bukhari, 1417 H). $\quad$ Juga, Rasulullah s\}allalla>hu 'alaihi wa sallam sempat melontarkan beberapa pertanyaan kepada Șayyād demi

\footnotetext{
8 Hal ini disebabkan karena beberapa hal, yaitu : 1 . Termasuk tanda kiamat besar, 2. Daabbah mencakup banyak jenis hewan, 3. Ada informasi valid bahwa daabah tersebut dapat berbicara.

${ }^{9}$ HR. Bukhari dalam Kitab Sahih-nya no. 7355.
} 
menguji derajat "kedajjalannya"10(AlBukhari, 1417 H).

Contoh yang lain dari interpretasi jenis kedua ini adalah ucapan Asmā binti Abu Bakar radfiyalla> hu 'anhuma di hadapan Hajjāj bin Yusuf, (artinya), "Sesunggubnya Rasulullab șallallābu 'alaibi wa sallam mengabarkan kepada kami babwa di kabilab Saqif akan ada seorang pendusta dan perusak, adapun sang pendusta maka kami telah menyaksikannya, adapun sang perusak, maka saya menduga engkau adalah dia"'1.

Menurut Asmā', yang dimaksud dengan Kaz\} $\left.\}_{z}\right\} a>b$ atau sang pendusta tersebut adalah Mukhtār bin Abi 'Ubaid Aś-Śaqafiy (An-Nawawi, 1392 H), dan Mubìr atau sang perusak tersebut menurut dugaannya adalah Hajjāj bin Yusuf Aś-Śaqafiy. Jika diteliti redaksi ucapan Asma', maka bentuknya adalah berupa dugaan, dan bukan memastikan. Sikap seperti ini adalah pilar yang penting dalam menginterpretasikan nas-nas dalam ranah realitas, padahal Hajjāj telah membunuh dan menyalib putra tercintanya, Abdullah bin Zubair radjiyalla>hu 'anhuma> (Ibnu Katsir, 1408 H).

Di antara persoalan yang perlu diungkap pula adalah bahwa sikap yang menonjol dari generasi salaf adalah sikap kehati-hatian dalam meriwayatkan hadis-hadis fitnah dan tanda-tanda kiamat. Di antara buktinya; bila ada hadis-hadis fitnah yang berpotensi menghadirkan 'kegaduhan' di tengah publik, atau berpotensi menimbulkan mudarat dan kerusakan di tengah masyarakat,

${ }^{10}$ HR. Bukhari: 1354

11 HR. Muslim : 6496. sedangkan riwayat (informasi) tersebut tidak berkonsekuensi pada amalan dan tidak berpengaruh pula pada hukumhukum syariat, maka mereka lebih memilih untuk tidak menyebarkan dan meriwayatkannya. ${ }^{12}$ Abu Hurairah rad\}iyalla>hu 'anhu mengatakan, (artinya), "Saya menghafal dua bejana hadis (yakni dua jenis hadis) dari Rasulullah șallallāhu 'alaibi wa sallam, salah satunya telah aku ajarkan, adapun yang satu bejana lagi, jika aku sebarkan maka leher ini akan disembelih"'".

Ibnu Hajar mengatakan, "Para ulama berpendapat bahwa hadis-hadis yang tidak disebarkan tersebut adalah hadishadis terkait penjelasan nama-nama umara (para penguasa) yang buruk, keadaan mereka serta zaman peristiwanya. Terkadang Abu Hurairah menyebarkan riwayat-riwayat tersebut, namun dengan menganonimkan nama-namanya dan tidak menyebutkannya dengan definitif, contohnya seperti ucapannya, (artinya), "Saya berlindung kepada Allah dari (peristiwa) yang akan terjadi pada awal tabun $60 \mathrm{H}$, dan dari pemerintahan anakanak" (Al-'Asqalani, 1379 H).

Sikap kehati-hatian seperti ini bukan hanya manhaj atau metodologi beliau secara pribadi, namun ia adalah metodologi para ulama salaf secara umum $^{14}$. Hużaifah bin Yamān rad\}iyalla>hu 'anhuma> mengisahkan, (artinya), "Rasulullah șallallähu 'alaibi wa sallam berdiri di hadapan kami (untuk berceramah), maka beliau tidak meninggalkan sesuatu pun berkaitan dengan peristiwa dan tanda

\footnotetext{
$12 \mathrm{Hal}$ ini adalah hasil konklusi penulis dari perkataan ulama yang disebutkan pada bagian setelahnya. 13 HR. Bukhari : 120.

${ }^{14} \mathrm{Hal}$ ini adalah hasil konklusi penulis dari perkataan Huzaifah yang disebutkan setelahnya.
} 
kiamat) kecuali menjelaskannya. Hal itu (isi ceramahnya) telah dibafal orang yang bisa menghafalnya, dan dilupakan oleh orang yang melupakannya. Para sababatnya telah mengetahuinya, dan terkadang ada sedikit informasi yang saya melupakannya, kemudian saya mengingatnya kembali, seperti seseorang yang melupakan orang yang dikenalnya jika berpisah, dan kembali mengenalnya tatkala berjumpa"15.

Dalam riwayat yang lain, Hużaifah bin Yamān radjiyalla>hu 'anhuma> mengatakan, (artinya), "Sesungguhnya saya adalah orang yang paling mengetabui terkait fitnah yang akan terjadi sampai bari kiamat, karena Rasulullah șallallähu 'alaibi wa sallam mengabarkannya kepadaku secara rahasia dan tidak mengabarkannya kepada orang lain"16.

Demikianlah ucapan Abu Hurairah dan Hużaifah bin Yamān radjiyalla>hu 'anhuma>. Mereka adalah para penghafal dan periwayat hadis-hadis Nabi, serta termasuk sahabat yang berspesialisasi dalam hafalan hadis-hadis terkait fitnah, sehingga dijuluki "Ṣahibu sirri Rasūlillāh" (Al-Mizzi, $1400 \mathrm{H}$ ) yang bermakna penjaga rahasia Rasulullah. Kedudukan yang mulia ini tidak menjadikan mereka berdua menyebarkan hadis-hadis tersebut secara serampangan tanpa mengukur maslahat dan mudaratnya. Hadis-hadis yang berpotensi menimbulkan fitnah dan kegaduhan di tengah umat, dan yang mewariskan sikap suuzan atau buruk sangka, saling mencurigai atau bermusuhan, apalagi jika hadis tersebut tidak memiliki konsekuensi pada hukum syariat dan amalan, maka tidak disebarkan di tengah umat islam.

${ }^{15}$ HR. Muslim : 7263.

${ }^{16}$ HR. Muslim : 7262.
Oleh karena itu, Hużaifah menyebarkan data nama-nama orang munafik ke tengah publik padahal beliau mengetahuinya, serta tidak menginformasikan nama-nama tokoh fitnah secara definitif padahal ada kemungkinan beliau juga mengetahuinya, sebagaimana ucapan beliau, (artinya), 'Demi Allah, saya tidak tabu; apakab teman-temanku lupa atau pura-pura lupa? Demi Allah, tidaklah Rasulullah menyisakan nama tokob-tokoh dalam fitnah sampai sirna dunia (terjadi kiamat) yang jumlabnya mencapai 300 orang lebih', kecuali beliau telah menyebutkan namanya, nama bapaknya dan nama kabilabnya"18.

Dari riwayat-riwayat ini ada satu pelajaran yang dapat dipetik, yaitu bahwa tidak semua informasi yang diketahui seseorang terkait masalah fitnah dan peristiwa-peristiwa tanda kiamat, dapat disebarkan kepada masyarakat umum, sebab Rasulullah șallallāhu 'alaibi wa sallam bersabda,

$$
\text { كَفَى بِالْمَزِِْ كَنِبًَا أَنْ يُحَدِّتَ بِكُلِّ مَا سَمِعَ }
$$

(artinya), "Cukup bagi sesesorang dijuluki pendusta, jika ia menginformasikan semua yang ia dengar". 19

\section{Hikmah dari Nas-nas Tentang Fitnah dan Tanda-tanda Kiamat}

Nas-nas yang ada dalam Alquran dan Hadis terkait fitnah akhir zaman dan tanda-tanda kiamat tidak hanya berupa kabar yang wajib diimani, tapi juga

\footnotetext{
17 Bandingkan dengan hadis yang diriwayatkan oleh Nu'aim bin Hammād dalam Kitāb Al-Fitan (1/31, no. 16).

18 HR. Abu Daud: 4241, dan dinyatakan lemah oleh AlAlbaniy dan Syu'aib Al-Arnā ūț.

${ }^{19}$ HR Muslim di Muqaddimah Shahih Muslim :7
} 
memiliki berbagai hikmah yang mesti diketahui, di antaranya sebagai berikut;

Pertama, sebagai bukti kebenaran risalah Nabi Muhammad s lallalla $>h u$ 'alaihi wa sallam. Hadis-hadis terkait fitnah dan tanda-tanda terjadinya kiamat sejatinya adalah di antara sekian bukti valid tentang kebenaran kenabian Nabi Muhammad s\}allalla> hu 'alaihi wa sallam, sebab hadis-hadis tersebut berkaitan dengan informasi peristiwa yang akan terjadi di masa mendatang yang merupakan bagian dari persoalan gaib, di mana informasinya hanya bisa diketahui oleh Allah semata (Al-Muthairi, 1429 H). Allah berfirman,

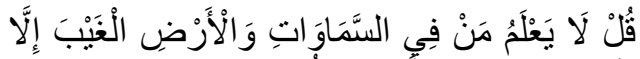

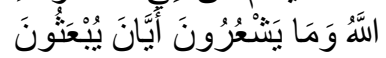

(artinya), "Katakanlab (wahai Mubammad), tiada sesuatu pun di langit maupun di bumi yang mengetahui perkara yang gaib kecuali Allah, dan mereka tidak. mengetabui kapan akan bangkitkan'20.

Ayat ini menafikan pengetahuan semua makhluk baik yang di langit maupun yang di bumi terkait perkara gaib, kemudian menetapkan pengetahuan perkara tersebut kepada Allah semata. Ini menunjukkan bahwa mengetahui perkara yang gaib adalah kekhususan bagi Allah Ta'a>la (AsSa'di, $1420 \mathrm{H}){ }^{21}$

Allah $T a^{\prime} a>l a$ juga berfirman,

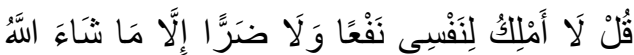

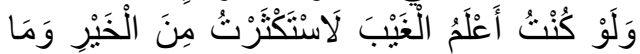

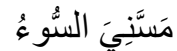

${ }^{20}$ QS. An-Naml: 65.

${ }^{21}$ Tafsir As-Sa'di hal. 608. (artinya), "Katakan (wahai Muhammad), sesunggubnya saya tidak kuasa mendatangkan manfaat apa pun maupun menolak. mudarat kecuali yang dikehendaki Allah. Sekiranya saya mengetabui perkara gaib niscaya saya akan memperbanyak melakukan sesuatu yang membawa manfaat bagiku dan akan jaub dari bahaya". 22

Ayat ini memaparkan bahwa Nabi Muhammad pun sejatinya tidak mengetahui perkara gaib dan apa yang beliau informasikan terkait hal tersebut merupakan wahyu yang Allah turunkan kepada beliau (As-Sa'di, 1420 $\mathrm{H})$. Allah berfirman,

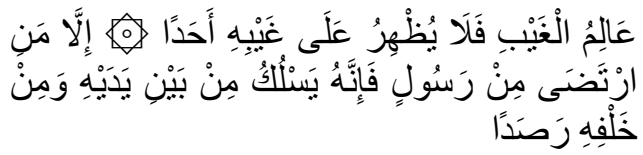

(artinya), "(Allab) mengetahui yang gaib, dan Dia tidak memperlibatkan perkara gaib tersebut kepada siapa pun kecuali kepada Rasul yang diridai-Nya. Maka sesunggubnya Dia mengadakan penjagaan (berupa malaikat) di depan dan di belakangnya',23.

Jadi, ayat-ayat dan hadis-hadis yang menginformasikan tentang perkara gaib merupakan bukti konkrit kebenaran risalah dan kenabian Nabi Muhammad sfallalla>hu 'alaihi wa sallam.

Kedua, salah satu ujian bagi keimanan hamba. Di antara sifat orang-orang yang beriman adalah mengimani perkara-perkara gaib, Allah $T a^{\prime} a>l a$ berfirman,

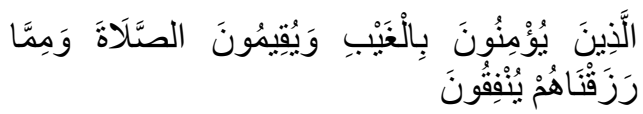

${ }^{22}$ QS. Al-A'rāf: 188.

${ }^{23}$ QS. Al-Jinn: 26-27. 
Website: https://journal.stiba.ac.id

ISSN : 2685-7537 (Online); 2338-5251 (Printed)

(artinya), "(Orang-orang bertakwa itu) adalah orang-orang yang beriman kepada yang gaib, menegakkan salat dan menafkabken sebagian rezeki yang Kami berikan kepada mereka,'24.

Mengimani perkara yang kongkrit dan yang kasat mata adalah hal lumrah, sebab itu ia bukanlah ujian hakiki bagi keimanan seorang hamba. Namun, ujian yang hakiki bagi keimanannya adalah keyakinannya kepada hal yang gaib, yaitu hal yang tidak dapat ditangkap oleh penglihatan mata, bahkan seringkali berada di luar nalar manusia. Perkara gaib ada tiga jenis ${ }^{25}$ :

a) Perkara gaib yang telah berlalu. Ini biasanya dalam bentuk kisah-kisah kaum terdahulu yang telah musnah, termasuk kisah para Nabi dan Rasul yang eksis dan hidup ribuan tahun sebelum Nabi Muhammad diutus.

b) Perkara gaib yang terjadi pada zaman sekarang (ketika seseorang hidup). Seperti perkara yang berkaitan dengan ajal, musibah, dan rezeki seorang hamba, sebab seorang hamba tidak mengetahui akhir ajalnya, waktu musibahnya, dan kadar rezeki yang akan diterimanya pada detik dan waktu saat dia hidup, bisa jadi detik itu dia meninggal atau mendapat musibah, atau memperoleh rezeki.

c) Perkara gaib yang akan terjadi di waktu mendatang. Seperti informasi terkait berbagai fitnah

${ }^{24}$ QS. Al-Baqarah: 3.

${ }^{25}$ Lihat

https://www.islamweb.net/ar/article/174099/\%D9\%85 \%D9\%86-\%D8\%AF\%D9\%84\%D8\%A7\%D8\%A6\%D9\%84\%D9\%86\%D8\%A8\%D9\%88\%D8\%A9-

\%D8\%A7\%D9\%84\%D8\%AD\%D8\%A8\%D9\%8A\%D8\%A8\%D8\%B5\%D9\%84\%D9\%89-

\%D8\%A7\%D9\%84\%D9\%84\%D9\%87-

\%D8\%B9\%D9\%84\%D9\%8A\%D9\%87-

\%D9\%88\%D8\%B3\%D9\%84\%D9\%85 atau huru hara yang akan terjadi, dan riwayat tentang tanda-tanda datangnya hari kiamat, khususnya tanda-tanda yang besar. Perkara ini selain termasuk perkara gaib, juga gambaran sebagiannya di luar nalar manusia, seperti; keluarnya Dajal, turunnya Nabi Isa, terbitnya matahari dari arah barat, dan munculnya Da>bbah (binatang raksasa).

Di antara tiga jenis perkara ini, jenis ketigalah yang paling dahsyat. Sebab untuk perkara pertama; seseorang dapat memperoleh informasi lewat kisah dan cerita orang-orang di sekitarnya, yang dinukil dari lisan ke lisan sampai zaman tersebut. Untuk perkara kedua; terkadang bisa diketahui lewat tanda-tanda tertentu, misalnya sakit berat yang menjadi salah satu tanda atau indikasi dekatnya ajal seseorang. Adapun perkara yang ketiga, maka tidak dapat dibuktikan dengan sesuatu apa pun, ia hanya berupa informasi yang mesti diimani secara kokoh di dalam sanubari. Sehingga inilah sebabnya informasi terkait tanda-tanda kiamat yang akan terjadi di masa akan datang menjadi salah satu ujian berat bagi keimanan seorang hamba.

Ketiga, agar seorang hamba mempersiapkan diri dalam menghadapi akhir dunia. Hal ini merupakan salah satu tujuan terbesar dari informasi tentang tanda-tanda kiamat, sebab jika seorang hamba melihat tanda-tanda hari kiamat terjadi sesuai yang dikabarkan oleh Rasulullah s\}allalla>hu 'alaihi wa sallam, maka dia akan terpacu untuk menyiapkan bekal bagi kehidupan setelah hari kiamat terjadi, berupa keimanan dan ketakwaan kepada Allah, dan giat 
melaksanakan ibadah kepada- $\mathrm{Nya}^{26}$. Oleh karena itu, ketika seseorang bertanya tentang waktu terjadinya hari kiamat kepada Rasulullah s\}allalla $>$ hu 'alaihi wa sallam, beliau justru balik bertanya kepadanya, (artinya), "Lalu apa yang engkau persiapkan untuk menyongsongnya?",27.

\section{Hukum Mendudukkan Kesesuaian Tanda-tanda Kiamat dengan Suatu Peristiwa atau Individu}

Dalam setiap masalah biasanya ada yang menyikapi secara ekstrim atau berlebih-lebihan, ada yang menyikapinya secara gegabah, dan ada pula yang menyikapinya dengan sikap pertengahan.

Yang dimaksud dengan sikap ekstrim dalam masalah ini adalah melarang praktik pendudukkan atau penyesuaian tanda-tanda kiamat yang ada dengan peristiwa atau individu tertentu secara mutlak. Tentunya pendapat ini kurang tepat, sebab ulama salaf mempraktikkan hal ini dalam beberapa keadaan sebagaimana yang telah kami jelaskan sebelumnya.

Adapun yang kedua, maksudnya adalah bermudah-mudahan dalam menetapkan kesesuaian nas-nas tersebut dengan beberapa peristiwa, melakukan sikap takalluf (pemaksaan) terhadap makna nas dalam penerapannya, bahkan memastikan atau hampir memastikan kesesuaian nas dengan satu peristiwa atau individu dalam praktik tersebut. Sikap seperti ini juga tentunya tidak dibenarkan.

${ }^{26} \mathrm{Hal}$ ini adalah konklusi dari hadits yang disebutkan di bawahnya.

${ }^{27}$ HR. Bukhari: 3688, dan Muslim: 6710.
Adapun sikap yang ketiga adalah praktik penentuan atau penyesuaian tanda-tanda kiamat pada realitas, namun dihiasi oleh dua hal, yaitu : pertama, harus memiliki kehati-hatian dalam menentukan atau menyesuaikannya, seperti memastikan dahulu kevalidan (kesahihan) riwayatriwayatnya, sebab hadis-hadis lemah sekali dan hadis palsu tidak bisa dijadikan pijakan dalam masalah ini, dan akan lebih baik jika ada ulama yang dijadikan panutan dalam pendapat tersebut; kedua, tidak memastikan kebenaran penentuan tersebut.

Dari tiga sikap ini, yang paling dekat dengan kebenaran adalah sikap yang ketiga. Cukup banyak praktik para ulama kontemporer yang mencocokkan tanda-tanda kiamat dengan peristiwa tertentu, di antaranya adalah tafsiran Abdul Aziz bin Baz terhadap sabda Rasulullah s\}allalla $>$ hu 'alaihi wa sallam,

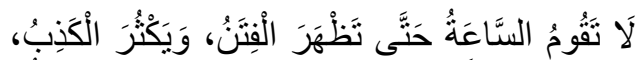

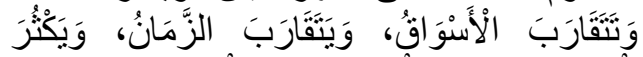

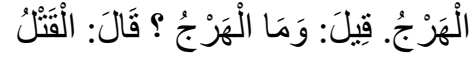

(artinya), "Tidak akan terjadi kiamat sampai banyak terjadi fitnah, menjamurnya dusta, berdekatannya pasar-pasar, mepetnya (singkatnya) waktu, dan banyaknya Harj". Kemudian ada yang bertanya, "Apa yang dimaksud dengan Harj?" Rasulullah menjawab, "Peperangan dan kekacanan"28.

Abdul Aziz bin Baz mengatakan, "Penafsiran yang lebih dekat dengan kebenaran terkait sabda Nabi (berdekatannya pasar-pasar, dan mepetnya

${ }^{28}$ HR Ahmad: 10724, sanadnya sahih. Lihat makna Harj di An-Nihāyah fí Garībil-Aśar (5/257). 
atau singkatnya waktu) yang ada dalam hadis adalah yang terjadi pada zaman ini berupa berdekatannya jarak antara satu kota dengan kota yang lain, dan pendeknya waktu untuk mencapai kota-kota tersebut, yang disebabkan oleh adanya penemuan-penemuan modern, berupa pesawat terbang, mobil dan alat-alat siaran (radio dan televisi) dan lain sebagainya"29.

Jika melihat penafsiran Abdul Aziz bin Baz di atas, maka bisa disiimpulkan beberapa hal, yaitu :

1. Penafsiran dan penyesuaiannya dengan realitas sangat logis.

2. Tidak terdapat sikap takalluf dalam penentuan peristiwanya.

3. Tidak menegaskan adanya kepastian secara mutlak dalam penafsirannya.

\section{Rambu-rambu Interpretasi Nas- nas tentang Tanda-tanda Kiamat}

Pasal ini merupakan tujuan inti dari tulisan ini yaitu pembahasan seputar kaidah dan rambu-rambu interpretasi nas-nas Alquran dan Hadis yang memaparkan tanda-tanda kiamat dan fitnah akhir zaman. Kaidah-kaidah ini dikonklusi dari kajian dan praktik para ulama salaf serta metodologi interaksi mereka dengan nas-nas tersebut. Jika ditelisik lebih lanjut, kaidah-kaidah ini akan kembali kepada dua perkara besar; pertama, sumber istidla $>l$ (pengambilan dalil) dan referensinya, dan kedua, metode konklusi dari referensi tersebut.

Kaidah pertama, sumber utama adalah Alquran dan Sunah. Salah satu anugerah yang Allah berikan kepada kaum muslimin adalah jelasnya

${ }^{29}$ Ucapan ini ada dalam catatan kaki Abdul Aziz bin Baz terhadap Fathul-Bārî (2/522). referensi dan sumber istidla $>l$ (pengambilan dalil) dalam beragama, baik dalam masalah akidah, ibadah, muamalah ataupun akhlak. Referensi tersebut adalah Alquran dan Sunah, keduanya merupakan referensi utama dan penting bagi umat Islam dalam mencari solusi bagi segala urusannya; urusan yang besar maupun yang kecil (Al-'Ujairi, $1433 \mathrm{H}$ ). ${ }^{30}$

Kaidah ini wajib diperhatikan oleh para praktisi yang terjun dalam dunia penentuan atau pencocokkan tandatanda kiamat dan fitnah pada peristiwa-peristiwa yang terjadi, sebab masalah ini berkaitan erat dengan akidah, apalagi jika penentuan tersebut hanya berupa asumsi atau prediksi kejadian yang akan terjadi di masa depan, maka penerapan kaidah ini lebih urgen lagi, karena berhubungan dengan perkara yang gaib.

Penyimpangan dan ketergelinciran dalam masalah ini akan terjadi jika praktik ini berpijak pada referensi lain selain dari dua hal di atas. Di antara referensi lain yang terkadang dijadikan landasan dalam praktik ini, adalah riwayat-riwayat non wahyu yang terdapat dalam kitab-kitab klasik, di antara referensi tersebut adalah :

\section{Hadis-hadis Manqüf}

Yang dimaksud hadis manqüf adalah ucapan atau perbuatan sahabat Nabi s\}allalla>hu 'alaihi wa sallam ${ }^{31}$. Pertanyaan yang muncul; bagaimana sikap terhadap riwayat-riwayat manqüf yang memiliki konten pembahasan terkait tanda-tanda kiamat, tentang sifat surga dan neraka, atau informasi

30 Lihat: Ma'ālim fĩ Tanzīl Nușūṣ Asyrāț As-Sā'ah, hal. 52.

${ }^{31}$ Al-Wadhih Fi Mushtalahil Hadits, hal. 92. 
terkait peristiwa yang akan terjadi di masa depan? ${ }^{32}$

Jawabannya adalah bahwa wajib melakukan verifikasi terlebih dahulu terhadap jenis riwayat mauqüf tersebut, apakah dihukumi sebagai hadis marfü $\bar{u}^{\prime}$ atau tidak. Riwayat atau hadis manqüf bisa dihukumi sebagai riwayat atau hadis marfü' (disandarkan kepada Nabi) dengan beberapa kriteria:

a) Konten dari riwayat tersebut bukan domain bagi ijtihad atau pendapat pribadi, seperti masalah pahala atau dosa suatu amalan, informasi terkait hal-hal yang gaib berupa; tanda-tanda kiamat, informasi terkait surga atau neraka dan lain sebagainya.

b) Riwayat tersebut disebutkan di dalam kitab-kitab hadis yang marf $^{\prime}$ (riwayat yang disandarkan kepada Rasulullah) dengan indikasi bahwa ia memiliki sumber dari Rasulullah s\}allalla $>$ hu 'alaihi wa sallam.

c) Sahabat yang meriwayatkan ucapan tersebut bukan orang yang masyhur sebagai pengkaji buku-buku Ahli Kitab, seperti Abdullah bin Salām dan Abdullah bin 'Amr bin 'Āṣ. Diinformasikan bahwa Abdullah bin 'Amr bin 'Āṣ. mendapatkan banyak buku Ahli Kitab dalam perang Yarmuk, dan beliau kemudian meriwayatkan dari buku tersebut berbagai informasi terkait perkara-perkara yang gaib (Al'Asqalani,1404 H).

d) Dan yang terpenting adalah mengikuti tuntunan para ulama pakar hadis dalam berinteraksi dengan riwayat-riwayat ini.

$32 \mathrm{Hal}$ ini terjawab dengan pembahasan di bawahnya.
Jika hadis tersebut masuk dalam kategori hadis marfü', maka boleh dijadikan referensi dalam masalah ini.

\section{Isrǟiliyyāt (riwayat-riwayat Ahli Kitab)}

Isrä ìliyyāt adalah riwayat-riwayat yang bersumber dari Ahli Kitab; yaitu kaum Yahudi dan Nasrani ${ }^{33}$. Yang unik dari Isräìiyyāt ini adalah kontennya yang sangat menarik, yaitu biasanya berisi informasi yang ajaib dan aneh, dan terkadang memaparkan perincianperincian yang tidak disentuh oleh hadis Nabi Muhammad s\}allalla>hu 'alaihi wa sallam, dan tentunya secara fitrah; mayoritas manusia sangat tertarik dengan informasi-informasi seperti ini (Ibnu Taimiyah, $1426 \mathrm{H}$ ). Namun, merupakan perkara aksiomatik pula, bahwa tidak semua informasi dari Isrä ìliyyät ini layak untuk disebarkan dan dikonsumsi oleh khalayak umum, apalagi jika berkaitan dengan riwayat-riwayat seputar perkara gaib ${ }^{34}$.

Banyak buku yang menjelaskan tentang tanda-tanda hari kiamat yang berpijak kepada Isrä ìliyyāt ini sebagai referensi penyempurna, dan mungkin referensi inilah yang menambah "keelokan" buku-buku tersebut sehingga sebagiannya menjadi best seller atau sebagian informasi yang dipaparkan di dalam buku tersebut menjadi ramai di tengah khalayak. Jika menelaah buku-buku yang telah kami sebutkan di awal tulisan ini, kita akan banyak mendapati bahwa banyak dari analisa-analisanya yang berpijak kepada sumber Isrä ililiyyāt.

${ }^{33}$ Lihat : Tafsirul Quran bil Israiliyat, Hal. 16

${ }^{34}$ Penjelasannya ada pada pembagian Isra'iliyat. 
Isrāilizyaàt ini terbagi dalam tiga macam:

Pertama, informasi yang terkandung di dalamnya sesuai atau diakomodir oleh ayat-ayat Alquran dan nas hadts-hadis Nabi yang sahih. Isrä ìliyyāt jenis ini boleh diriwayatkan sebagai pendamping bagi dalil yang dimiliki, namun ada catatan kecil yang patut diketahui, bahwa hujah itu hanya tegak dengan dalil dari Alquran Sunnah dan bukan dengan Isrä ìiliyyät tersebut.

Kedua, informasi yang dikandungnya bertolak belakang dengan dalil-dalil yang sahih. Jenis ini tidak boleh diajarkan dan disebar kepada masyarakat kecuali dengan tujuan menjelaskan kelemahan atau ketidakvalidannya, sehingga masyarakat tidak tertipu dengan riwayat-riwayat seperti ini.

Ketiga, informasi yang dikandungnya tidak didukung dan diakomodir oleh dalil dari Alquran dan Sunnah dan tidak ada pula yang menolaknya. Maka kita harus bersikap tawaqquf dengan Isräìliyyāt jenis ini, yakni tidak mempercayai kontennya dan tidak pula mendustakannya (Ibnu Taimiyah, $1426 \mathrm{H})$.

Klasifikasi Isrä ìliyyāt dengan tiga jenis ini sangat masyhur di kalangan ulama, bahkan hampir semua ulama menyepakatinya.

Dalam suatu hadis, Rasulullah sfallalla>hu 'alaihi wa sallam bersabda,

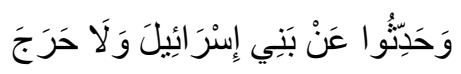

(artinya), "Dan kabarkanlah riwayatriwayat dari Bani Israil, dan itu tidak mengapa's5.

Ibnu Kasīir mengatakan tentang hadis ini, "Maksudnya adalah riwayat Isrä iliyyyat yang didiamkan oleh syariat, di mana tidak ada nas dari syariat yang membenarkannya atau yang menolaknya (mendustakannya), maka boleh meriwayatkannya dengan tujuan untuk memetik pelajaran darinya, dan inilah yang kami praktikkan di kitab ini (Al-Bidāyah wa An-Nihāyah). Adapun Isrā ìliyyaùt yang dibenarkan oleh dalildalil dalam Islam, maka hal tersebut tidak dibutuhkan karena sudah termasuk di dalam syariat. Sedangkan Isrä iliyyaàt yang didustakan oleh dalildalil dalam syariat, maka ia tertolak dan tidak boleh disebarkan kepada khalayak kecuali untuk dijelaskan kedustaannya" (Ibnu Katsir, 1408 H).

Jadi, faedah tertinggi dari Isrà ìliyyāt adalah agar kita bisa memetik pelajaran darinya, dan ia tidak bisa dijadikan sebagai landasan hukum dalam syariat, apalagi dijadikan pijakan dalam mencocokkan tanda-tanda kiamat ke dalam dunia nyata, sebab perkara ini dikategorikan bagian dari perkara gaib.

Kaidah kedua, verifikasi kevalidan hadis-hadis. Kaidah ini termasuk kaidah yang sangat urgen. Berhujah dengan hadis harus memperhatikan dua sisi, yaitu : pertama, memastikan kevalidan hadis tersebut; dan kedua, memperhatikan makna hadis dan korelasinya dengan hukum tertentu.

Jadi, tidak boleh berhujah dengan hadis kecuali telah memastikan dua hal ini, dan ini merupakan perkara

35 HR. Bukhari: 3461 
aksiomatik bagi para ulama hadis. Ibnu Qudāmah mengatakan, "Adapun hadis-hadis palsu yang disebarkan oleh orang-orang zindik dengan tujuan menebar syubhat di tengah kaum muslimin, atau hadis-hadis yang lemah, baik kelemahannya disebabkan karena kelemahan perawi, atau mereka tidak dikenal (majhūl), atau karena adanya 'illah (kelemahan) di dalam hadis tersebut, maka tidak boleh dijadikan dasar hukum, dan tidak boleh juga diyakini kandungannya" (Al-Maqdisi, $1406 \mathrm{H}$ ).

Bahkan Ibnu Taimiyah menukil kesepakan para ulama dalam masalah ini, "Melakukan istidläl (memetik kesimpulan hukum) dari hadis yang tidak diketahui kevalidannya adalah haram menurut kesepakatan para ulama, sebab hal tersebut dikategorikan berkata tanpa ilmu, dan praktik ini diharamkan menurut Alquran, Sunnah dan Ijmak" (Ibnu Taimiyah, $1406 \mathrm{H})$.

Cukup banyak hadis-hadis Nabi s\}allalla>hu 'alaihi wa sallam yang berisi ancaman bagi orang yang meriwayatkan hadis-hadis yang palsu, di antaranya adalah sabda Rasulullah sfallalla $>$ hu 'alaihi wa sallam,

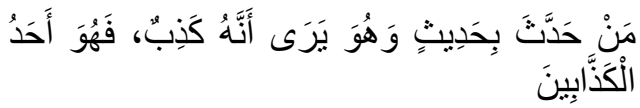

(artinya), "Barang siapa yang meriwaytakan hadis, yang ia tabu babwa hadis tersebut adalab dusta, maka ia adalab salah satu pendusta's6.

Praktik mendudukkan atau mencocokkan tanda-tanda kiamat dengan peristiwa atau individu tertentu

${ }^{36}$ HR. Ahmad: 18211. sangat rentan terpapar dengan hadishadis jenis ini, apalagi jika berpijak kepada hadis-hadis yang diriwayatkan oleh Nu'aim bin Hammād di dalam kitabnya, Al-Fitan, sebab sangat banyak hadis-hadis lemah, munkar dan palsu yang terkandung di dalamnya.

Aż̇̇̇ahabiy mengatakan, "Nu'aim bin Hammād termasuk salah satu wadah ilmu (ulama berwawasan luas), namun jiwa ini tidak condong kepada riwayatriwayatnya $^{37 ، 6}$ (Azzahabi, $1405 \mathrm{H}$ ).

Abu Ali An-Naisābūriy mengatakan, "Saya mendengar Abu Abdullah AnNasā iy memuji Nu'aim bin Ḥammād, dan menyebutkan keunggulannya dalam ilmu dan pengetahuan. Kemudian An-Nasāà ditanya, 'Apakah hadis-hadisnya diterima dan kuat?' Maka beliau menjawab, 'Banyak hadisnya yang menyelisihi hadis ulama-ulama yang masyhur dalam bidang hadis, sehingga hadis-hadis yang diriwayatkannya masuk dalam kategori tidak bisa dijadikan hujah" (Azzahabi, $1405 \mathrm{H}$ ).

Penilaian Aż-Żahabiy terhadap Nu'aim bin Hammād; "Tidak boleh bagi seorang pun berhujah dengannya, dia menulis Kitab Al-Fitan, dan banyak hadis-hadis yang aneh dan mungkar di dalamnya" (Azzahabi, 1405 H).

Ibnu 'Adiy dalam Kitab Al-Kämil fi Du'afä Ar-Rijäl mencoba untuk menginventarisir riwayat-riwayat Nu'aim bin Ḥammād yang dianggap lemah dan mungkar, dan berpendapat ada sebagian hadis Nu'aim bin Hammād yang lurus dan valid. Intinya adalah wajib memverifikasi hadis-hadis yang diriwayatkan oleh beliau,

${ }^{37}$ Maksudnya hadis-hadisnya banyak yang lemah. 
khususnya yang diriwayatkan di dalam Kitab Al-Fitan.

Hadis mungkar termasuk dalam kategori hadis yang lemah ${ }^{38}$, maka tidak bisa dijadikan dasar hukum dan pijakan dalam menetapkan tandatanda kiamat (Yusram, 2017).

Di antara hadis palsu riwayat Nu'aim bin Hammād yang ramai akhir-akhir ini adalah hadis tentang "suara dahsyat" yang akan terjadi di akhir zaman, yang redaksinya, (artinya), Abu Umar mengabarkan kepada kami, dari Ibn Lahî'ah, ia berkata, "Abdul Wahhāb bin Husain mengabarkan kepada kami", dari Muhammad bin Sāait Al-Bunāniy, dari ayahnya, dari Al-Hāris̉ Al-Hamdāniy, dari Ibnu Mas'ūd, dari Nabi s\}allalla>hu 'alaihi wa sallam bahwa beliau bersabda, "Apabila telah terdengar suara dabsyat di bulan Ramadan, maka akan terjadi buruhara di bulan Syawal. Semua suku akan saling berselisib di bulan Zulkaedah, dan akan terjadi pertumpahan darah di bulan Zulhijah dan Mubaram. Tahukah kalian (yang akan terjadi) di bulan Mubaram?" Nabi menyebutkan hal tersebut sebanyak 3 kali-. "Celakalah, di masa itu manusia akan banyak yang terbunub". Para sahabat pun bertanya, "Suara keras apakah itu, wahai Rasulullab?" Beliau menjawab, "Suara keras yang terjadi di pertengahan Ramadan, pada malam jumat. Suara dabsyat itu mengagetkan orang-orang yang sedang tertidur, menjadikan orang berdiri terjatuh, para wanita terhempas keluar dari kamarnya, pada malam jumat di tabun tersebut banyak terjadi gempa bumi. Jika kalian telah melaksanakan salat subuh di hari jumat pada pertengaban Ramadan tersebut, masuklah kalian ke dalam rumah-

38 Lihat : Al-Wadhih fi Mushtalahi, hadis hal. 177. rumah kalian, tutuplah pintu-pintunya, tutuplab lubang-lubangnya, lindungi diri kalian dengan selimut, dan tutuplab telinga kalian. Jika kalian merasakan adanya suara yang dabsyat maka sujudlab kepada Allah dan ucapkanlab: "SubhānalQuddūs... Subh̄ōnal-Quddūs... RabbunalQuddūs". Sebab siapa yang melakukannya niscaya akan selamat, dan yang tidak. melakukannya akan binasa',59.

Hadis ini sanadnya sangat lemah, bahkan bukan hanya satu perawi yang lemah, namun ada enam sekaligus, mereka adalah:

a) Nu'aim bin Ḥammād bin Muawiyah Al-Marwaziy, sang penulis Kitab Al-Fitan. Ia merupakan sosok yang diperselisihkan derajatnya oleh para ulama Al-Jarh wa $A t-T a^{\prime} d i \bar{l}$ (Al-Mizzi, $1400 \mathrm{H}$ ), ada ulama yang memuji dan menilainya sebagai perawi Siqah, namun cukup banyak dari kalangan ulama yang mengkritik dan melemahkannya, di antaranya adalah Abu Daud, dan AnNasā iy (Azzahabi, 1405 H). Ibnu Hajar Al-'Asqalāniy setelah mengkaji, membandingkan dan menimbang pandangan para ulama di atas, beliau menyimpulkan bahwa Nu'aim bin Hammād ini; Sadūq, namun banyak kesalahannya dalam meriwayatkan hadis (Al-'Asqalani, 2005).

b) Abu Umar dalam riwayat ini merupakan nama yang mubmal dan tidak diketahui secara pasti siapa personnya, karena nama ini mencakup banyak personal. Di dalam kitab Al-Fitan, Nu'aim bin Hammād meriwayatkan beberapa

${ }^{39}$ HR. Nu'aim bin Ḥammād dalam Kitab Al-Fitan : 638. 
hadis dari jalur Abu Umar ini, dan sebagian jalurnya disebut dengan nama Abu Umar Aṣ-Ṣaffār (AlMarwazi, $1412 \mathrm{H}$ ) yang bernama asli Ḥammād bin Wāqid Abu Umar Aș-Ṣaffār. Imam Bukhari mengatakan tentangnya, "Munkarul-Hadīs" (Al-Bukhari, t.th). Yahya bin Ma'ìn mengatakan bahwa ia "lemah", dan Abu Ḥātim Ar-Rāziy dan Abu Zur'ah mengatakan, "Hadisnya lemah" (Ar-Razi, $1271 \mathrm{H}$ ).

c) Ibnu Lahîah, namanya adalah Abdullah, lengkapnya Abdullah bin Lahî'ah Al-Haḍramiy AlMișriy. Ibnu Hajar mengatakan tentangnya, "Șadūq, hafalannya campur baur setelah bukunya terbakar" (Al-'Asqalani, 2005).

d) Abdul Wahhāb bin Husain, adalah perawi majbül (tidak diketahui derajatnya dalam $A l$ Jarh wa $A t-T a^{\prime} d i \bar{l}$ sebagaimana dikatakan oleh Al-Hākim. ${ }^{40}$

e) Muhammad bin Ṡābit bin Aslam Al-Bunāniy, beliau adalah perawi yang lemah (Al-'Asqalani, 2005).

f) Al-H̄āris̉ Al-Hamdāniy, julukannya adalah Al-A'war, ia perawi yang lemah, bahkan sebagian menuduhnya sebagai pendusta (Al-'Asqalani, 2005).

Inilah mata rantai sanad dari hadis di atas. Tanpa perlu melakukan penelitian yang mendalam seseorang bisa menghukumi sanad hadis di atas secara mudah serta dapat menyimpulkan bahwa sanad hadis tersebut sangat cacat dan sangat lemah, bahkan para ulama kita memvonis hadis di atas dengan derajat terendah dalam hadis; yaitu palsu!

${ }^{40}$ Lihat Al-Mustadrak (4/566), nomor hadis 8590.
Oleh karenanya, jelaslah kedudukan dan derajat hadis ini; yaitu palsu menurut kesepakatan para ulama hadis. Jika hadis ini derajatnya adalah palsu, maka konsekuensinya tidak dapat dijadikan sebagai hujah menurut kesepakatan para ulama hadis juga.

Namun, ada sebagian ustaz dan dai ${ }^{41}$ yang masih nekat meriwayatkan hadis ini, bahkan diringi dengan prediksi pula, bahwa hadis ini ada kemungkinan berlaku pada tahu 1441 $\mathrm{H}$, yang kemudian akan diiringi dengan munculnya Al-Mahdi beberapa bulan setelah itu, sebab tahun ini tanggal 15 Ramadan jatuh pada hari Jumat sebagaimana yang diisyaratkan dalam hadis di atas. Tentunya ini sangat ironis, sebab hujah yang kandungannya mereka prediksikan tersebut derajatnya palsu sebagaimana telah dijelaskan di atas.

Kaidah ketiga, hukum asal nas adalah dipahami sesuai makna lahirnya. Di antara kaidah Ahli Sunnah yang masyhur adalah membawa makna nas pada makna lahirnya, yaitu bahwa makna nas yang terbetik dalam benak itulah yang dimaksud dengan makna lahir, dan makna ini tidak dipelesetkan (ditakwilkan) ke makna lain kecuali ada dalil dan indikasi kuat yang menunjukkannya.

Dalil-dalil yang terkait dengan tandatanda kiamat, secara prinsip, masuk juga dalam kategori nas yang harus dibawa kepada makna lahirnya. Menginterpretasi nas-nas tanda-tanda kiamat dengan menyelewengkan makna lahirnya, padahal tidak ada dalil atau indikasi untuk proses itu, mewariskan kesan ingin mempercepat

${ }^{41}$ Lihat:

https://www.youtube.com/watch?v=NiHsEuQ55hM 
datangnya hari kiamat, apalagi jika makna lahirnya tidak mendukung penetapan kesesuaiannya dengan realitas yang ada.

Salah satu contoh dari penyelewengan dalam kaidah ini adalah, terkait dengan tersingkapnya gunung emas di sungai Eufrat, sebagaimana sabda Rasulullah s\}allalla $>$ hu 'alaihi wa sallam,

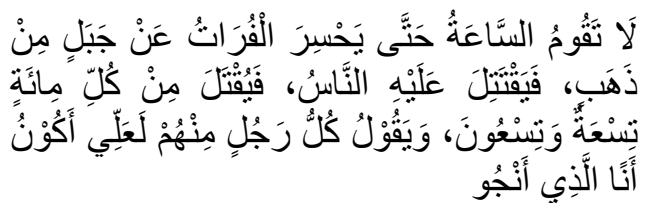

(artinya), "Kiamat tidak akan terjadi bingga sungai Eufrat mengering airnya bingga tersingkap gunung emas, maka manusia pun saling berperang untuk memperebutkannya, dan terbunub 99 orang dari setiap 100, dan semua yang bertikai mengatakan: sayalah yang akan selamat (sehingga mendapatkan emas) ${ }^{\text {‘t2 }}$.

Hadis ini jelas pemaparannya, bahwa yang akan tersingkap dari sungai Eufrat adalah gunung emas atau emas yang sangat banyak. Sebagian peneliti kontempoter menyelewengkan makna hadis ini dari makna lahirnya, bahwa yang dimaksud dengan gunung emas dalam hadis ini adalah minyak ${ }^{43}$, sebab minyak masyhur juga dengan istilah Aż-Żahab Al-Aswad alias emas hitam.

Tentunya interpretasi ini telah keluar dari makna lahir nas, dan interpretasi ini tertolak karena beberapa faktor:

a) Menyeleweng dari makna lahir hadis, dan tidak ada dalil atau indikasi yang "mewajibkan" untuk dimaknai di luar makna lahir tersebut.

42 HR. Muslim : 7272.

43 Lihat: Komentar penyunting Kitab An-Nihāyah filFitan wal-Malāḥim, karya Ibnu Kasīir (1/208). b) Redaksi hadis mengatakan "jabal min żahab", dan lafal "jabal" yang artinya gunung identik dengan benda yang keras dan padat, sangat berbeda dengan minyak, yang identik dengan sesuatu yang lembek dan cair, maka seyogyanya redaksi hadisnya menggunakan lafal "bahr" (lautan) atau lafal yang semisalnya (Al-Mubayyadh, $1415 \mathrm{H})$.

c) Redaksi hadis menunjukkan ada penyusutan air yang masif di sungai Eufrat, sehingga "gunung emas" tersebut nampak dan kelihatan sehingga menggelitik orang-orang untuk memperebutkannya, hal ini berbeda dengan minyak, yang mana minyak dikeluarkan dari dalam bumi, dan membutuhkan peralatan yang berat dan sulit untuk memanfaatkannya ${ }^{44}$.

Kaidah keempat, penetapan kesesuaian tanda kiamat dengan peristiwa yang terjadi tidak terkesan dipaksakan (takalluf). Sejatinya kecocokan tanda-tanda kiamat dengan peristiwa-peristiwa yang ada terjadi secara natural, tidak ada sifat takalluf (dipaksa-paksakan) dalam pencocokkan atau penyesuaiannya.

Contohnya, seperti tanda-tanda kiamat berupa diutusnya Nabi Muhammad Sallallāhu 'alaibi wa sallam, wafatnya beliau, banyak kekacauan dan fitnah, merebaknya kebodohan terhadap ilmu agama, dihalalkannya musik, serta zina dan khamar. Semua tanda-tanda kiamat ini dapat diterapkan kepada zaman tertentu secara alamiah, bahkan sebagian orang awam pun dapat memahami tanda-tanda ini. Sikap

${ }^{44}$ Idem. 
takalluf atau memaksakan diri dalam menetapkan kesesuaian nas-nas tanda kiamat dengan realitas terkadang sangat tendensius, yaitu "memaksakan" tanda-tanda tersebut sudah terjadi atau hampir terjadi, dan biasanya terkait dengan tanda-tanda yang diringi dengan keluarnya Imam Mahdi, karena munculnya Imam Mahdi merupakan pintu untuk terjadinya tanda-tanda kiamat besar. Sehingga, pembahasan tanda-tanda kiamat jenis ini serta penetapannya dalam peristiwa realitas sangat menarik minat masyarakat.

Salah satu contohnya adalah penentuan realitas dari kandungan hadis Rasulullah s\}allalla>hu 'alaihi wa sallam (artinya), "Akan berperang di "barta simpanan" kalian tiga orang, semuanya adalab anak khalifah, kemudian barta tersebut tidak ada seorang pun yang dapat menguasainya dari mereka, kemudian muncul bendera-bendera bitam dari arah timur, mereka akan memerangi kalian dengan sangat dabsyat"45.

Ada sebagian dai yang menafsirkan nas di atas dengan sengkarut pemilihan waliyyul-'ahd (putra mahkota) yang terjadi di Kerajaan Arab Saudi pada masa Raja Salman bin Abdul Aziz. Tentunya ada aroma takalluf berlebihan dalam hal ini, karena dua faktor:

a) Sengkarut dalam urusan suksesi kepemimpinan adalah hal yang lumrah, pasti ada saling sikut di dalamnya, apalagi dalam sistem kerajaan, pasti banyak yang merasa lebih berhak untuk menjadi putra mahkota dibandingkan yang lainnya, bukan hanya tiga orang saja yang

${ }^{45}$ HR. Ibnu Majah: 4084, dan dilemahkan oleh Syu'aib Al-Arnā'ūṭ dan Al-Albāniy. berselisih, hanya saja dalam konteks Kerajaan Saudi Arabia, hal tersebut biasa dapat disamarkan dengan lobi-lobi tingkat tinggi antara keluarga kerajaan.

b) Menurut pengamatan penulis, hadis ini pernah juga diterapkan kesesuaiannya pada pemerintahan Raja Fahd beberapa dekade yang lalu, bahkan yang dituduh berselisih pada zaman tersebut salah satunya adalah Pangeran Salman (Raja Saudi sekarang), dan dua orang lainnya, yaitu Pangeran Sultan dan Pangeran Abdullah (Raja Arab Saudi pasca Raja Fahd) (Jamaluddin, t.th.).

Namun, ternyata prediksi ini gagal, dan sekarang dicari sosok lain sebagai penafsiran makna dari hadis ini, yaitu Raja Salman dan sengkarut pemilihan putra mahkota yang mengiringinya, tentunya dibumbui dengan berbagai macam justifikasi, dan pelacakan pihak yang berselisih tersebut. Jika ternyata prediksi ini meleset lagi, maka berapa banyak umat islam yang akan menjadi korban penentuan makna hadis ini? Sungguh, aroma takalluf sangat kental dalam penerapan ini.

Jadi, perlu diketahui, ketika proses pencocokkan hadis ini dengan suatu peristiwa sedang berlangsung, dan tokohnya sudah ditentukan, maka akan timbul buruk sangka, kebencian dan mungkin juga permusuhan kepada tokoh-tokoh tersebut. Inilah salah satu dampak negatif dari praktik penafsiran seperti ini.

Kaidah kelima, bersikap hati-hati dalam menetapkan kesesuaiannya dengan realitas dan tidak gegabah. Salah satu kaidah dalam mendudukkan 
hadis-hadis terkait tanda-tanda kiamat adalah berhati-hati dan tidak gegabah, sebab proses ini adalah proses yang pelik dan dapat menimbulkan dampak negatif yang tidak kecil. Abdullah bin Mas'ùd mengatakan, (artinya), "Sesungguhnya akan terjadi kekacauan, kerusakan, dan munculnya perkara-perkara musytabihät (yang samar), maka wajib bagimu untuk berbias dengan kehati-hatian, sehingga engkau menjadi pengikut kebaikan, dan hal tersebut lebih baik, daripada engkan menjadi tokoh keburukan (dengan tindakan gegabahmu) ${ }^{\prime 46}$.

Sikap gegabah ini terkadang mewariskan metodologi yang sangat sederhana dalam mendudukkan hadishadis tanda kiamat ini. Sebagai contoh: prediksi bahwa Imam Mahdi akan muncul pada tahun $2024 \mathrm{M}$ atau sebelumnya ${ }^{47}$ yang merupakan salah satu interpretasi terhadap hadis Rasulullah s\}allalla>hu 'alaihi wa sallam, (artinya), "Sesunggubnya Allab mengutus untuk umat ini di akbir setiap seratus tabun sosok yang memperbaharui agamanya" ${ }^{\text {,48 }}$.

Perhitungannya; kekhalifahan Usmaniyah di Turki jatuh pada tahun 1924 M, maka jika menelisik hadis di atas, kemudian diterapkan ke dalam realitas, maka tahun $2024 \mathrm{M}$ atau sebelumnya sedikit adalah tahun munculnya Imam Mahdi yang akan memimpin umat Islam dan mendirikan khiläfah 'alà minhäj annubuwwah seperti yang diisyaratkan oleh Rasulullah s\}allalla>hu 'alaihi wa sallam. Jadi, sang mujaddid yang dijanjikan oleh hadis di atas adalah Imam Mahdi versi prediksi tersebut,

${ }^{46}$ HR. Ibnu Abi Syaibah : 38343.

${ }^{47}$ Lihat

https://www.youtube.com/watch?v=RESEpcZ9s0A

48 HR. Abu Daud : 4291. padahal hadis di atas sejatinya tidak memiliki korelasi dengan Imam Mahdi, bahkan yang dimaksud dalam hadis adalah para ulama. Al-'Azịim Ābādiy memaknai mujaddid tersebut dengan menyatakan, "yaitu sosok yang menjelaskan perkara-perkara yang sunnab dari yang bidah, menyebarkan ilmu dan menolong para ulama, serta mengalabkan abli bidah dan menghinakannya. Para ulama mengatakan babwa hal ini tidak akan bisa dilakukan kecuali oleh seorang alim (banyak ilmunya) terbadap ilmu agama baik lahir maupun yang batin". (Aabadi, $1415 \mathrm{H})$.

Sebuah pertanyaan terbetik, mengapa yang menjadi ukuran aplikasinya adalah tahun masehi dan bukan tahun hijriyah? Sebab biasanya hal-hal yang bersifat syar'i sangat identik dengan kalender hijriyah. Dan juga perlu penjelasan; apa yang di maksud dengan "ra'su mi ati sanah" (ujung seratus tahun), apakah yang dimaksud adalah di awal, atau di pertengahan, atau di akhir seratus tahun?

Al-'Aẓīm Ābādiy mengatakan, "Dalil yang jelas bahwa yang dimaksud " $r a$ 'su mi ab" adalah akhir dari seratus tahun dan bukan awalnya adalah pendapat Az-Zuhriy dan Ahmad bin Hanbal serta kesepakatan para ulama bahwa sang mujaddid di seratus tahun pertama adalah Umar bin Abdul Aziz, dan sang mujaddid di seratus tahun kedua adalah Imam Asy-Syāfi'iy, yang mana Umar bin Abdul Aziz wafat pada tahun 101 $\mathrm{H}$, dan Imam Asy-Syāfi'iy wafat pada tahun 204 H” (Aabadi, $1415 \mathrm{H}$ ).

Yang kami paparkan ini adalah sampel yang banyak tersebar di media social terkait prediksi akhir zaman, jika kita menilik lebih jauh, maka tidak lepas dari sikap gegabah dan takalluf dalam 
mengaplikasikan dan mencocokkan nas-nas tanda-tanda kiamat dengan realitas.

Kaidah keenam, tidak menetapkan penentuan tahun atau waktu terjadinya tanda kiamat. Kaidah ini adalah rambu-rambu yang sangat urgen terkait dengan masalah yang kita bahas, apalagi jika membahas tandatanda kiamat yang belum terjadi, maka penentuan tahun, bulan dan waktu tertentu hendaknya dihindari, contohnya seperti yang telah kami paparkan dalam kaidah yang kelima.

Hal ini juga telah diwasiatkan oleh para ulama kita yang terdahulu, seperti Șiddīq Hasan Khān, ketika beliau menjelaskan makna malhamah, beliau mengatakan, "Namun informasi terkait waktu yang definitif terjadinya fitnah dan peperangan tersebut adalah perkara yang disembunyikan oleh Allah dari makhluknya, sangat sulit bagi manusia untuk mengetahuinya, dan mereka mengetahuinya setelah terjadinya peristiwa tersebut" (AlQanuji, 1978).

Al-Qurțūbiy juga mengatakan, "Yang harus ditegaskan dalam bab ini; bahwa yang diinformasikan oleh Nabi Muhammad șallallāhu 'alaibi wa sallam terkait fitnah dan peristiwa-peristiwa besar pasti terjadi, adapun penentuan waktu terjadinya fitnah dan peristiwaperistiwa tersebut bahwa akan terjadi di tahun tertentu, maka membutuhkan cara yang benar untuk digunakan sebagai alasan yang kuat, sebab waktu terjadinya tanda-tanda kiamat di atas sama seperti waktu terjadinya kiamat itu sendiri, tidak ada seorang pun yang mengetahuinya" (Al-Qurthubi,1425 $\mathrm{H})$.
Setelah diteliti lebih jauh, ternyata upaya penentuan waktu turunnya Imam Mahdi telah ada sejak zaman dulu, dan upaya tersebut berakhir dengan kegagalan dan kekecewaan, sebagaimana persaksian Ibnu Khaldūn (732-808 H) dalam Kitab Muqaddimahnya ${ }^{49}$.

Di antara ulama yang memastikan tahun munculnya Imam Mahdi adalah Al-Barzanjiy rahimabulläh (1040-1103 H) dalam bukunya Al-Isyä'ah, beliau mengatakan, "Menurut perhitungan, kemungkinan besar kemunculan Mahdi akan terjadi di akhir 100 tahun yang pertama (maksudnya $1100 \mathrm{H}$ ), dan jika tertunda, maka kemunculannya tidak akan meleset melebihi akhir 100 tahun kedua (yaitu sekitar tahun $1200 \mathrm{H}$ ) ${ }^{\prime 50}$.

Namun ternyata pada hari ini, zaman sudah melewati 100 tahun ke empat setelah seribu tahun dari hijrahnya Nabi Muhammad s\}allalla $>h u$ 'alaihi wa sallam ke Madinah.

Kesalahan fatal prediksi Al-Barzanjiy terkait tahun munculnya Mahdi ini malah tidak dijadikan pelajaran oleh orang-orang yang hidup setelahnya, salah satunya adalah Fahd Sālim yang memprediksi datangnya Dajal pada tanggal 15 Syakban $1420 \mathrm{H}$ (23 November 1999 M), dengan diiringi fitnahnya yang sangat besar berupa pengakuan ketuhanannya ${ }^{51}$. Seakan Fahd Sālim ini tidak mengetahui, bahwa apa yang diprediksikannya itu adalah fitnah dan musibah yang sangat besar bagi dirinya dan bagi kaum muslimin.

${ }^{49}(2 / 816)$.

50 Hal. 139.

51 Lihat : Asyrāț As-Sā'ah, hal: 146, dan Ma'ālim fi

Tanzīl Nușūṣ Asyrāț As-Sā'ah, hal: 218. 
Kaedah ketujuh, tidak memastikan kebenaran interpretasi tersebut. Ini merupakan sifat yang harus melekat pada orang yang berspesialisasi membahas tema hari kiamat dan tanda-tandanya, dan telah kami isyaratkan di awal tulisan ini.

Penentuan tanda-tanda kiamat dalam peristiwa realitas biasanya hanya berpijak pada zan (dugaan) semata, sebab itu, tidak etis jika kemudian memastikan penentuan tersebut meskipun terkadang ada kemiripan yang besar, apalagi jika dalil-dalil yang dijadikan pijakan lemah atau bahkan palsu.

Memastikan terjadinya suatu informasi yang akan terjadi di masa depan atau suatu peristiwa sebagai bagian dari tanda-tanda kiamat bisa dilakukan dalam dua keadaan:

Pertama, ada ijmak atau konsensus ulama terkait dengan kecocokan tanda tersebut dengan dalil. Contohnya adalah pencocokkan Asmā' binti Abu Bakar terhadap hadis tentang kemunculan dua orang dari kabilah Śaiff, sang pendusta dan sang perusak, sebagaimana disebutkan dalam Sahih Muslim, (artinya), "Sesungguhnya Rasulullah mengabarkan kepada kami bahwa di kabilah Saqif akan ada seorang pendusta dan perusak, adapun sang pendusta maka kami telah menyaksikannya, adapun sang perusak, maka saya menduga engkau adalab dia' ${ }^{152}$.

Penentuan Asmā’ binti Abu Bakar tentang sosok "sang perusak" kepada Mukhtār bin 'Ubaid Aś-Śaqafiy dibagun atas dasar ijmak. Oleh karena

52 HR. Muslim : 6496. itu, beliau menggunakan kata ganti (kami) dalam riwayat di atas, adapun penentuan sosok "sang perusak"

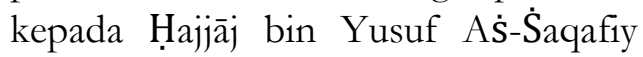
maka dibangun atas dugaan. Namun, ternyata ada ijmak di kalangan ulama terkait ${ }^{53}$ kecocokan penentuan ini, dan Imam Nawawilah yang menukil ijmak tersebut (An-Nawawi, $1392 \mathrm{H}$ ).

Kedua, peristiwa tersebut telah terjadi. Banyak praktik para ulama terkait dengan keadaan kedua ini, contohnya adalah penaklukan Baitulmaqdis, bahwa peristiwa ini terjadi pada zaman Umar bin Al-Khattab radiyalalla $>h u$ 'anhu (Ibnu Katsir, 1408 H). Di antara tanda kiamat yang disinyalir sudah terjadi adalah melimpahnya harta di tengah kaum muslimin, bahwa ini terjadi pada zaman penaklukan di zaman sahabat dan tabiin, dan juga melimpahnya harta di zaman Umar bin Abdul Aziz ${ }^{54}$.

\section{KESIMPULAN}

Berdasarkan pembahasan di atas, dapat disebutkan beberapa poin kesimpulan, yaitu :

Pertama, jenis interpretasi nas-nas tentang tanda-tanda kiamat ini ada dua, yaitu : pertama, mendeskripsikan nas-nas tersebut dan memaparkan sifat dan rincian peristiwanya sesuai yang dikandung oleh nas tersebut dan selaras dengan penjelasan para ulama; kedua, mendudukkan kesesuaian nasnas terkait tanda-tanda kiamat pada peristiwa atau tokoh tertentu, atau memprediksikan terjadinya tandatanda kiamat pada waktu, bulan atau

\footnotetext{
53 Penjelasan ini berfokus pada ijmak atau konsensus ulama, sebagai contoh bolehnya penentuan pencocokan tanda kiamat.

${ }^{54}$ Lihat : Asyrāṭ As-Sā'ah, Yusuf Al-Wābil, hal. 88-89.
} 
tahun tertentu. Diantara hikmah keberadaan nas-nas dalam Alquran dan Hadis terkait akhir zaman dan tanda-tandanya adalah sebagai bukti kebenaran risalah Nabi Muhammad, sebagai salah satu ujian bagi keimanan hamba, di antara sifat orang-orang yang beriman adalah mengimani perkara-perkara gaib, dan agar seorang hamba mempersiapkan diri dalam menghadapi akhir dunia;

Kedua, hukum mendudukkan kesesuaian tanda-tanda kiamat dengan suatu peristiwa atau individu adalah boleh, dengan syarat memenuhi dua hal, yaitu: pertama, harus memiliki kehati-hatian dalam menentukan atau menyesuaikannya, seperti memastikan dahulu kevalidan (kesahihan) riwayatriwayatnya; kedua, tidak memastikan kebenaran penentuan tersebut. Rambu-rambu atau kaidah yang wajib diperhatikan dalam interpretasi nasnas terkait hari kiamat adalah menjadikan Alquran dan sunah sebagai sumber utama, melakukan verifikasi kevalidan hadis-hadis, hukum asal nas adalah dipahami sesuai makna lahirnya, penetapan kesesuaian tanda kiamat dengan peristiwa yang terjadi tidak terkesan dipaksakan (takalluf), bersikap hati-hati dalam menetapkan kesesuaiannya dengan realitas dan tidak gegabah, tidak menetapkan penentuan tahun atau waktu terjadinya tanda kiamat, dan tidak memastikan kebenaran interpretasi tersebut.

\section{DAFTAR PUSTAKA}

Aabadi, Muhammad Syamsul Haq Al'Adhim.(1415 H). 'Aunul Ma'bud Syarb Sunan Abi Dawud. Cetakan pertama, Beirut, Darul Kutub Ilmiyah.
Ahmad, W. A. W., Abidin, A. F. M. Z., \& Mohamed, Y. (2018). Analisis Gambaran Perumpamaan Tentang Hari Kiamat dalam Juzuk Amma. Journal of Fatwa Management and Research, 676-686.

Al-Albani, Muhammad Nashiruddin. $(1412 \mathrm{H})$. Silsilah Al-Abadits AlDha'ifah wal Maudhu'ah. Cetakan pertama, Riyadh, Darul Ma'arif.

Al-'Asqalani, Ahmad bin 'Ali bin Hajar.(1379 H). Fathul Bari Syarh Shabih Al-Bukhari. Beirut, Darul Ma'rifah

Al-'Asqalani, Ahmad bin 'Ali bin Hajar.(1404 H). An-Nukat 'Ala Kitabi Ibnus Shalah. Cetakan pertama, Al-Madinah AlMunawwarah, Imadah Al-Bahts Al-ilmi Bil Jamiah Al-Islamiyah.

Al-'Asqalani, Ahmad bin 'Ali bin Hajar. (2005 M). Taqribut Tahrib. Oman, Baitul 'Afkarid Dauliyah.

Al-Barzanji, Muhammad bin Rasul. (1426 H). Al-Isya'ab Li Asyrathis Sa'ah. Cetakan ketiga, Jeddah, Darul Minhaj.

Al-Bukhari, Muhammad bin Ismail. $(1417$ H). Shabih Al-Bukhari. Cetakan pertama, Riyadh, Darus Salam.

Al-Bukhari, Muhammad bin Ismail. (t.th). Tarikh Al-Kabir. India, Dairatul Ma'arif Al-Utsmaniyah.

Al-Hakim, Muhammad bin Abdullah Abu Abdillah. (1411 H). AlMustadrak 'Alash Shabihain. Cetakan pertama, Mesir, Darul Kutub Ilmiyah.

Al-Jauzi, Abdurrahman bin 'Ali. (1386

H). Al-Maudhu'at. Cetakan pertama, Madinah AlMuawwarah, Maktabah Assalafiyah.

Al-Jauziyah, Ibnul Qayyim. (1390 H). Al-Manar Al-Munif. Cetakan 
pertama, Aleppo, Maktabah AlMathbua'at Al-Islamiyah.

Al-Jazari, Al-Mubarak bin Muhammad bin Athir. (1399 H). An-Nibayah fi Gharibil Hadits Wal Athar. Beirut, Al-Maktabah Ilmiyah.

Al-Maqdisi, Abdullah bin Ahmad bin Qudamah. (1406 H). Zammut Ta'wil. Cetakan pertama, Kuwait, Darus Salafiyah.

Al-Marwazi, Nu'aim bin Hammad. (1412 H). Kitabul Fitan. Cetakan pertama, Kairo, Darut Tauhid.

Al-Mizzi, Yusuf bin Zaki. (1400 H). Tahribul Kamal fi Asmair Rijal. Cetakan pertama, Beirut, Muassasah Risalah.

Al-Mubayyadh, Muhammad Ahmad. (1415 H). Al-Mausu'ah fil Fitan wal Malabimwa Asyratus Sa'ah. Cetakan pertama, Mesir, Muassasah Al-Mukhtar.

Al-Muthairi, Abdulmuhsin. (1429 H). Al-Adillah Al-jaliyah 'Ala Shidqi Khairil Bariyah. Riyadh, Majallah Al-Bayan.

Al-Qanuji, Shiddiq Hasan Khan Abut Thayyib. (1978 M). Abjadul Ulum. Beirut, Darul Kutub Ilmiyah.

Al-Qazwini, Muhammad bin Yazid. (t.th). Sunan Ibnu Majah. Cetakan pertama, Riyadh, Maktabatul Ma'arif.

Al-Qurthubi, Muhammad bin Ahmad. (1425 H). At-Tazkirah fi Abwalil Mauta wa Umuril Akbirah. Cetakan pertama, Riyadh, Darul Minhaj.

Al-'Ujairi, Abdullah bin Shalih. (1433 H). Ma'alim fi Tanzili Nushusi Asyrathis Sa'ah 'Alal Waqa'i wal Abdats. Cetakan pertama, Saudi Arabiyah Muassasah Durar Saniyyah..

An-Naisaburi, Muslim bin Haijaj. $(1421$ H). Shabih Muslim.
Cetakan kedua, Riyadh, Darus Salam.

An-Nawawi, Yahya bin Syaraf. (1392 H). Al-Minbaj Syarb Shabih Muslim bin Hajjaj. Cetakan dua, Beirut, Dar Ihyaut Turots AlArabi.

Ar-Razi, Abdurrahman bin Muhammad bin Idris. (1271 H). Kitab Al-Jarh wat Ta'dil. Cetakan pertama, India, Dairatul Ma'arif Al-Utsmaniyah.

As-Sajistani, Sulaiman Bin Ath'ath. $(1417 \mathrm{H})$. Sunan Abi Dawud. Cetakan kedua, Riyadh, Maktabatul Ma'arif.

As-Sa'di, Abdurrahman bin Nashir. $(1420$ H). Taisir Karimir Rabman fi Tafsiri Kalamil Mannan. Cetakan pertama, Beirut, Muassatur Risalah.

Asy-Syaibani, Ahmad bin Hanbal. $(1416 \mathrm{H})$. Al-Musnad. Cetakan pertama, Beirut, Muassatur Risalah.

Asy-Syihri, Zahir bin Muhammad bin Said. (t.th.). Manqif Ablis Sunnah wal Jama'ah min Tanrilin Nushusil Fitan Wa Asyrathis Sa'ah 'Alal Hawadith. Riyadh, Tesis untuk meraih gelar master di Universitas Al-Malik Su'ud.

Azzahabi, Muhammad bin Ahmad bin Utsman. (1405 H). Siyar A'lamun Nubala. Cetakan ketiga, Beirut, Muassasah Risalah.

Che'Had, S. B. (2018). Penafsiran Ayat tentang Hari Kiamat menurut Umar Sulaiman'Abdullah AlAsyqar. Doctoral Dissertation, UIN Ar-Raniry Banda Aceh.

Fauziah, N. (2013). Penafsiran ayatayat kiamat dalam tafsir AlJawahir Fi tafsir Al-Quran AlKarim karya Thantawi Jauhari. Doctoral Dissertation, UIN Sunan Gunung Djati Bandung. 
Ghaith, Muhammad bin Ghaith. (1434 H). Abadith Asyratus Sa'ab wa Fiqhuba Dirasab Ta'shiliyah. Maroko, Disertasi untuk meraih gelar doktor di Universitas Muhammad Al-Khamis.

Ibnu Abi Syaibah, Abdullah bin Muhammad. (1427 H). Mushannaf Ibni Abi Syaibah. Cetakan pertama, Darul Qiblah.

Ibnu Katsir, Ismail bin Umar AdDimasyqi. (1408 H). Al-Bidayah wan Nihayah. Beirut, Dar Ihyaut Turats Al-'Arabi.

Ibnu Katsir, Ismail bin Umar AdDimasyqi. (1408 H). An-Nihayah Fil Malahim wal Fitan. Beirut, Darul Jil.

Ibnu Taimiyah, Taqiyuddin Ahmad bin Abdulhalim. (1406 H). Minhajus Sunnab An-Nabawiyyah. Cetakan pertama, Riyadh, Jamiah Al-Imam Muhammad bin Su'ud Al-Islamiyah.

Ibnu Taimiyah, Taqiyyuddin Ahmad bin Abdulhalim. (1426 H). Majmu'ul Fatawa, Darul Wafa'.

Iskandar, A., Aqbar, K. (2019). Reposisi Praktik Ekonomi Islam: Studi Kritis Praktik Ekonomi Islam di Indonesia. NUKHBATUL 'ULUM : Jurnal Bidang Kajian Islam, 5(1), 39-53.

Jamaluddin, Amin Muhammad. (t.th.). Harmajidun Akbirul Bayan $\mathrm{Ya}$ Ummatal Islam. Mesir, AlMaktabah At-Taufiqiyah.

Khozin, K. (1996). Penafsiran AyatAyat Mutasyabihat Tentang Hari Kiamat Menurut Para Mufassir. Doctoral Dissertation, UIN Sunan Ampel Surabaya.

Yusram, M. (2017). Hukum Meriwayatkan dan Mengamalkan Hadis Daif untuk Fadhail al-A'mal.
NUKHBATUL 'ULUM : Jurnal Bidang Kajian Islam, 3(1), 1-11. 